\title{
New Application of Powder Injection Molded Product in Medical Field
}

\author{
Jakub Huba $^{1,2}$, Daniel Sanetrnik ${ }^{1,2}$, Eva Hnatkova ${ }^{1,2}$, Berenika Hausnerova ${ }^{1,2}$, Zdenek Dvorak $^{1,2}$ \\ ${ }^{1}$ Department of Production Engineering, Faculty of Technology, Tomas Bata University in Zlin, Vavreckova 275, \\ 76001 Zlin, Czech Republic. \\ ${ }^{2}$ Centre of Polymer Systems, Tomas Bata University in Zlin, Trida T. Bati 5678, 76001 Zlin, Czech Republic \\ E-mail: jhuba@ft.utb.cz,dsanetrnik@ft.utb.cz, ehnatkova@ft.utb.cz, hausnerova@ft.utb.cz, zdvorak@ft.utb.cz
}

Nowadays, majority part of powder injection molding (PIM) market in Europe consists in automotive (43 \%). In contrast, to medical applications only $13 \%$ of market is devoted. This paper is focused on a new design and production technology of the adenoid cutting curette used in otorhinolaryngology. In the theoretical part, the present design issues of the cutting curette are shown, and time consumption and wear problems of sterilisation are described. Experimental part consists in selection of suitable metal powder for medical application, computeraided engineering (CAE) Moldflow analysis of proper gating system followed by construction of injection mold and production of real samples. The new design of replaceable cutting edge is easily customized according to various shapes of patient oral cavity and for doctor's need.

Keywords: PIM, Adenoid, Otorhinolaryngology, Medical Device, Curette.

\section{Acknowledgement}

This work was supported by the Ministry of Education, Youth, and Sports of the Czech Republic - Program NPU I (LO1504). This study was also supported by the internal grant of TBU in Zlin IGA/FT/2016/002 funded from the resources of the specific university research. The authors would like also to thank MUDr. Vladimir Zlinsky who works for Otolaryngology Clinics, Trida T. Bati 3929, 76001 Zlin, Czech Republic for his collaboration, consultations and professional medical advices.

\section{References}

[1] GERMAN, R. M, BOSE, A. (1997). Injection Molding of Metals and Ceramics. Priceton, New Jersey.

[2] HEANEY, D. F. (2012). Handbook of metal injection molding. Woodhead Publishing Limited, Cambridge.

[3] GERMAN, R. M. (2011) Metal injection molding, A comprehensive MIM design guide. Princeton, NY.

[4] RAK, Z. S. (1999). New trends in powder injection moulding. Powder metallurgy and metal ceramics, vol. 38(4), pp.126-132.

[5] HAUSNEROVA, B. (2011). Powder Injection Molding - An Alternative Processing Method for Automotive Items, New Trends and Developments in Automotive Systems Engineering, pp. 130-146.

[6] HAUSNEROVA, B., SANETRNIK, D., PONIZIL, P. (2013). Surface structure analysis of injection molded highly filled polymer melts, Polymer Composites, Vol. 34, pp. 1553-1558.

[7] GASBARRE, T.G., JANDESCA, W.F. (1989). Advances in Powder Metallurgy, Metal Powder Industries Federation, Princeton, NJ.

[8] HAUSNEROVA, B., MARCANIKOVA, L., FILIP, P., SAHA P. (2011). Optimization of powder injection molding of feedstock based on aluminium oxide and multicomponent water-soluble polymer binder. Polymer Engineering \& Science, vol. 51(7), pp. 1376-1382.

[9] RATNER, B. D. (2004). Biomaterials Science: An Introduction to Materials in Medicine. Academic Pres, Amsterdam.

[10] WILLIAMS, N. (2012). PM2012 World Congress: Special Interest Seminar Reveals Strong Global Growth for PIM, with Asia Leading the Way. Powder injection moulding international, vol. 6(4), p.47.

[11]SIDAMBE, A. T., FIGUERO, I. A., HAMILTON, H. G. C., TODD, I. (2012). Metal injection moulding of CP-Ti components for biomedical applications, Journal of Materials Processing Technology, vol. 212(7), pp.1591-1597.

[12]NEWELL, M. A., DAVIES, H. A., MESSER, P. F., GREENSMITH, D. J. (2005). Metal injection moulding of scissors using hardenable stainless steel powders, Powder metallurgy, vol. 48(3), pp.227-230. 